УДК 659.133:316.3-043.2

\section{Цитування:}

Chernysh M., Demchenko H. The problem of psychological impact of the advertising poster on society [Проблема психологічного впливу рекламного плакату на суспільство]. Вісник Національної академії керівних кадрів культури $i$ мистещтвв : наук. журнал. 2020. №3. С. 83-87.

Chernysh M., Demchenko H. (2020). The problem of psychological impact of the advertising poster on society. National Academy of Culture and Arts Management Herald: Science journal, 3, 83-87 [in Ukrainian].
Chernysh Marianna,

cand. of cultural studies, associate professor of the department of drawing and painting, Kyiv national university of technology and design

ORCID: https://orcid.org/0000-0001-7379-1489

mc18852@gmail.com

Demchenko Hanna,

master's degree, faculty of design, Kyiv national university of technology and design

ORCID: https://orcid.org/0000-0001-5123-3558

anutochka-2011@ukr.net

\title{
THE PROBLEM OF PSYCHOLOGICAL IMPACT OF THE ADVERTISING POSTER ON SOCIETY
}

The purpose of the article is a research of the modern advertising poster. As we study the poster, we study the psychological impact of the advertising poster on society. Our goal is to identify the means of the impact of modern advertising on the consumer and to evaluate the trend of development. Methodology. The methodological basis is based on the principle of a systematic approach and a comprehensive study of modern advertising. To analyze the psychological impact of the poster on the society we use: empirical and theoretical methods. We have considered the method of comparative analysis on the basis of literature on the topic of research, as well as scientific and methodological documentation. The systematization of the material is based on analysis and synthesis techniques. Scientific novelty. The scientific article investigates the means of the psychological influence of advertising on society for the first time. On the basis of our research, the definition of visual means and compositional principles of construction of advertising, substantiation of the expediency of the poster, and aesthetic appeal with the use of stylistic design, the effects of the psychological influence of the poster on the society are considered. Conclusions. To sum up, we conclude that advertising manipulates our subconscious. Analyzing the publications and trends of the poster development, it is revealed that it has long ceased to be of informative nature only and is considered as a means of influencing human consciousness. By imposing new values, it shapes attitudes towards the world and turns one into a doer of external will. Unfavorable results of social processes exacerbate stress, and work on the problem begins. As a result, it is concluded that public banners should not interpret social difficulties, but offer alternatives focused on the emotions of love, etc.

Key words: poster, advertising poster, modern poster, social impact, psychological impact.

Черниш Маріанна Олегівна, кандидат культурології, доцент кафедри рисунка та живопису Київського наиіонального університету технологій та дизайну; Демченко Ганна Павлівна, магістр факультету дизайну Київського наиіонального університету технологій та дизайну

Проблема психологічного впливу рекламного плакату на суспільство

Метою дослідження $\epsilon$ розвиток сучасного рекламного плакату. Через дослідження плакату ми розглядаємо, як сучасний рекламний плакат психологічно впливає на суспільство. Нашою метою $є$ визначення засобів впливу сучасної реклами на споживача та оцінення тенденції розвитку реклами. Методологія дослідження. За методологічну основу взято принцип системного підходу та комплексного дослідження сучасної реклами. Для аналізу психологічного впливу плакату на суспільство використано загальнонаукові методи дослідження: емпіричні та теоретичні, метод аналізу спеціалізованих ресурсів та наукових публікацій за тематикою. Нами було розглянуто метод порівняльного аналізу на основі літературних джерел за темою дослідження, а також нормативної науково-методичної документації. Систематизований матеріал здійснений на основі прийомів аналізу та синтезу. Наукова новизна. У науковій статті нами досліджено вперше, як засоби сучасного рекламного плакату психологічно впливають на суспільство. На основі нашого дослідження, визначення образотворчих засобів та композиційних принципів побудови реклами, обгрунтування доцільності рекламного плакату та естетичної привабливості, завдяки використанню стилістики дизайну, розглянуті наслідки психологічного впливу рекламного плакату на суспільство. Висновки. Підводячи підсумки, можна дійти висновку, що реклама вправно маніпулює нашою підсвідомістю. Аналізуючи публікації та дослідивши сучасні тенденції розвитку плакату, виявили, що вона давно перестала нести просто інформаційний характер і

(C) Chernysh M., 2020

(C) Demchenko H., 2020 
вважається одним 3 найсильніших засобів впливу на людську свідомість. Зараз нав 'язуючи нові цінності, установи, вона формує ставлення до світу, і перетворює людину на виконавця сторонньої волі. Несприятливі результати соціальних процесів збільшують стресовість, і починається робота на проблему, її культивація. В наслідок чого,дійшли до висновку що громадські банери мають не інтерпретувати соціальні труднощі, породжуючи страхи, а пропонувати альтернативи фокусуючи увагу на емоціях любові, веселощів, патріотизму i що аналогічне.

Ключові слова: плакат, рекламний плакат, сучасний плакат, вплив на суспільство, психологічний вплив.

Черныш Марианна Олеговна, кандидат культурологии, дочент кафедры рисунка и живописи, Киевский национальный университет технологий и дизайна; Демченко Анна Павловна, магистр, факультет дизайна, Киевский национальный университет технологий и дизайна

Проблема психологического воздействия рекламного плаката на общество

Целью исследования является развитие современного рекламного плаката. Через исследования плаката мы рассматриваем как современный рекламный плакат психологически влияет на общество. Нашей целью является определение средств воздействия современной рекламы на потребителя и оценки тенденции развития рекламы. Методология. За методологическую основу взят принцип системного подхода и комплексного исследования современной рекламы. Для анализа психологического воздействия плаката на общество использованы общенаучные методы исследования: эмпирические и теоретические, метод анализа специализированных ресурсов и научных публикаций по тематике. Нами были рассмотрены методы сравнительного анализа на основе литературных источников по теме исследования, а также нормативной научно-методической документации. Систематизированный материал осуществлен на основе приемов анализа и синтеза. Научная новизна. В научной статье нами исследовано впервые, как средства современного рекламного плаката психологически влияют на общество. На основе нашего исследования, определение изобразительных средств и композиционных принципов построения рекламы, обоснование целесообразности рекламного плаката и эстетической привлекательности, благодаря использованию стилистики дизайна, рассмотрены последствия психологического воздействия рекламного плаката на общество. Выводы. Подводя итоги, можно сделать вывод, что реклама умело манипулирует нашим подсознанием. Анализируя публикации и исследовав современные тенденции развития плаката, обнаружили, что она давно перестала нести просто информационный характер и считается одним из самых сильных средств воздействия на человеческое сознание. Сейчас навязывая новые ценности, она формирует отношение к миру, и превращает человека в исполнителя посторонней воли. Неблагоприятные результаты социальных процессов увеличивают нервозность, и начинается работа на проблему, ее культивация. В результате чего, пришли к выводу что общественные баннеры должны не интерпретировать социальные трудности, порождая страхи, а предлагать альтернативы фокусируя внимание на эмоциях любви, веселья, патриотизма и аналогичное.

Ключевые слова: плакат, рекламный плакат, современный плакат, влияние на общество, психологическое воздействие.

Relevance. In the modern world, advertising is a communication that has been introduced into all spheres of life, so the need for its research is undeniable. Analysis of scientific works make it possible to conclude that there is insufficient research on the advertising poster because there is insufficiently disclosed influence on society. Because the poster is really the most common form of outdoor advertising, it is important to study the mechanisms of its psychological impact on humans, and by what means this influence is achieved.

An analysis of research and publications. In the XI - XX centuries, advertising was considered to be a method of influencing consumers, and still, this opinion is accepted by modern researchers.

In 1923, Professor of the Psychological Institute of Wurzburg University T. Koenig stated that commercial advertising is an influence on a person in order to cause the need to buy the product being advertised. The buyer's assuredness of the need for such a product as the main condition for sales efficiency was not considered by them. To study this psychological impact, he chose an experimental method. The professor of the Higher Trade School Lipsky assured that only in this way the right conclusions can be reached.

T. Koenig analyzed the theory of the German scientist B. Vities, which was published in the article in 1905 . He explained, "why advertising continues to make a significant impact on the public, despite the fact that society understands, in theory, the vested interests and purpose of advertising, and because of that fact, as well as because of its experience, the society is mistrustful and skeptical towards promises and lures of advertising» $[5,108]$. He said that people have the ability to borrow ready-made concepts and to make these judgments a mental influence on them. Advertising is able to make not only your problem relevant but also to convince you of the need for products, without objective reasons.

Nowadays, scientists are convinced that advertising can create the need for an advertised product in empty space, affect people's understanding and shape the needs of humanity. 
However, the question still remains: why do people buy products they do not need? As a result, there are many unexplored issues that need further investigation.

The purpose. Research on modern advertising posters. Through the study of the poster, we examine the psychological impact of modern advertising posters on society. Our goal is to identify the means of the influence of modern advertising on the consumer and to evaluate the trend of advertising development.

Presenting the main material. The poster's history dates back to ancient times. A poster and an affiche are considered to be the most ancient means of attracting human attention. This is a public message intended to conclusions and specific actions.

The predecessors of the modern poster are German large-scale engravings in the period of the Peasant War, which were called «flying sheets» and acted as propaganda.

With the development of theatrical arts in Western Europe, theatrical posters have been expanded, with the help of which the population was informed about the coming performances. In fact, today we see advertising posters used for similar purposes. In the nineteenth century, lithographs were involved in their creation, which enhanced the influential and visual characteristics of posters.

Famous masters of the USA and Western Europe turned to poster art: J. Shere, M. Wrubel, P. Bonnar, E. Hess, E. Penfield, D. Hardy, O. Fisher, G. Klimt, and many others. The designs created by Jules Schere and Henri ToulouseLautrec are considered particularly striking and have greatly influenced the poster's further development. In the period of 1866-1900, J. Shere produced more than 1000 posters and made history not only as of the author of the first artistic model but also as a popularizer of the new genre [7, 275]. His posters are similar to paintings with a historical plot, full of characters where it is difficult to find the main character, in the future the number of characters was reduced.

A. Toulouse-Lautrec showed his mastery in lithographic theatrical posters, demonstrating graphic-sharp laconicism, decorative color display, and a bizarrely-flexible drawing. The posters made by him attest to the inexhaustible imagination, graphic courage, and brilliant skill of the artist [1,134].

Many artists of the XX century appealed to the creation of a poster through the agitation of political parties in different directions. Today, the poster is very advanced and has become a complex language, but the visual aids and compositional principles of construction have remained unchanged since then.

A poster is the most widespread form of publicity and awareness-raising tool aimed at addressing social issues. This is a message to the public that is used as an informative, psychological, social tool, but it depends on what the goal is. Submitted information is designed to have a brief impact on the viewer, so the basic ideas of the posters should be clear.

The poster works in different conditions, so when it is perceived, one or another kind of attention is always included. Attention can occur involuntarily, through an orienting reflex, or at will, when a person has an interest in receiving information.

Posters that cause involuntary attention usually have an unusual shape, dynamism, originality, color contrast. Attention is drawn involuntarily and lasts for a period of time until the person has mastered meaningful and aesthetic information. Such posters are considered effective, so the knowledge and use of psychological techniques of attracting attention determine the success of the designer.

Arbitrary attention occurs when the viewer selects the object of study and the background fades into the background.

In order to focus the person on the main thing in the poster, the center of the composition is made more drawn, and exhibit a favorable level of contrast. The main information is collected and better understood by a person. The perception of the poster goes from the center of the composition and moves to another part so that all the parts that make up the composition are cognized consistently.

Using slogans is one of the most popular methods of advertising. It is easy - to - remember the phrase that expresses the essence of an advertising message and aims to convey basic advertising information. It is important to have an association with the product, and it is desirable to adhere to the primary colors of the spectrum for better perception.

If the ads are effective, at relatively low cost, the advertiser can raise their rating to high levels, reaching a large audience in a short amount of time. External advertising media can use effects such as light and animation, which attracts attention when going to the supermarket, subway, etc.

The task of advertising is to keep up with the times. In today's world, trends are constantly changing so that your advertising will be effective, it's important to keep up. The impact of advertising on society can be observed at the 
example of a well-known brand. «Coca - Cola» is considered to be one of the most famous and expensive brands. Not everyone is able to look fresh and stylish for 125 years while remaining recognizable. However, the company is investing great resources in developing new solutions, including design. Due to this, they are still able to surprise their customers with new promos.

The famous New Year's «Coca - Cola» advertisement first appeared in the 1920s and forever changed the image of Santa Claus. Trademark representatives wanted to root this character (before Santa Claus was portrayed differently - for example, a tall and thin man or elf). This image was recreated by illustrator Huddon Sandble. His original oil portraits of this character were used in every «Coca-Cola» advertisement. Since then, Santa Claus has become an integral part of the brand.

In the 1920s, Cola first began selling six bottles in its packaging. This technique helped make bulk purchases more convenient and larger sales. In 1928, it was recorded that the number of bottles sold was exceeding the amount of bottled carbonated water for the first time.

In 2007, a new bottle design was presented in France that was comfortable to hold due to its shape. In this regard, the Marcel agency launched a series of advertising boards that literally «clung» to passers-by. The posters were made of textile velcro material that clung to the garment but did not spoil it. These billboards were installed at public transport stops in Paris. As a result, the company's share in the French market has increased compared to the previous year.

In 2010, in Toronto, Canada, they launched an outdoor advertising campaign where «CocaCola» defeated the idea of drinking a beverage with tubes. They were literally sticking out of posters and billboards, treating everyone to a drink. In this way, designers were able to incorporate elements of architecture, exterior, and even other advertisements designed specifically for this campaign. The concept and design were developed by McCann Advertising Agency.

In 2014, the Belgian agency «Duval Guillaume» launched an advertising campaign for «Coca-Cola» on «Packaging Paper» called «Discover Happiness». For this purpose, several different variants of branded wrapping paper were designed. To find happiness, you must first pack it. Each passerby could tear off a piece of packaging paper labeled «Discover happiness» literally from the advertising board and pack their own gifts.

One of the most valuable examples of outdoor advertising was the 3D Coca Cola billboard on Times Square in New York. With the traffic of over 300,000 people a day, the square has become a symbolic place for the company. The brand's advertising was first installed there in 1920. Already in August 2017, «Coca Cola» launched the world's first and the tallest $(20 \times 12$ m) 3D billboard, for which it won two Guinness Awards. The billboard consists of 1760 LED screens that move independently, but together create the effect of a smooth transition of the picture in reality. The IT and marketing department of the company, in collaboration with many partners, worked on creating and testing the billboard for 4 years.

A striking example of Coca-Cola's unusual advertising design was the world's first knit billboard in Serbia. Serbs love and attach themselves to their own traditions. A global brand like «Coca-Cola» has joined traditional national craft to become closer to the buyer. The billboard series is just the beginning of a broader campaign that introduced national cuisine.

The quality of outdoor advertising of any enterprise depends first and foremost on the correctness of management decisions, but every organization is an open system that is influenced by society and exists only in interaction with the environment.

However, advertising only works properly when it is well thought out and well-executed. Otherwise, the effect will be negative and detrimental to both the company and the consumer. The key negative factors of affecting are that the advertising imposes patterns of thinking, behavior, gives people the idea that if he or she acquires one or another thing, then he or she will be happy, successful, better in status. People of society view themselves and others not on their own merits, but on what they possess. In this way, a value system is developed that focuses only on consumption. But not everything can be purchased, it leads to the emergence of an inferiority complex in humans. This is most common for young people, but in adulthood because of marketing pressure, it is impossible to satisfy all advertising needs which are sometimes artificially created and that leads to stress. The vast majority of us are well aware that what we are convinced of is not entirely true, but we are fascinated by the flickering of commercials, and in the store, we select the goods of untwisted brands without thinking. Whether we want it or not, advertising not only gives us ideas of behavior in a particular situation but also largely determines the morale of society and its mood.

Scientific novelty The scientific article investigates the means of the psychological 
influence of advertising on society for the first time. On the basis of our research, the definition of visual means and compositional principles of construction of advertising, substantiation of the expediency of the poster, and aesthetic appeal with the use of stylistic design, the effects of the psychological influence of the poster on the society are considered.

Conclusions. To summarize, we can conclude that advertising is skillfully manipulating our subconscious. Analyzing publications and examining current trends in the development of the poster, it is revealed that it has long ceased to be simply informational in nature and is considered one of the most powerful means of influencing human consciousness. Now imposing new values, institutions, it shapes the attitude to the world and turns a person into a doer of an outside will. Unfavorable results of social processes increase stress, and work begins on the problem, its cultivation. As a result, it was concluded that public banners should not interpret social difficulties, generating fears, but offer alternatives focusing on emotions of love, fun, patriotism, and the like.

\section{Лimepamypa}

1. Андрейканіч А.I. Визначення поняття плаката, його види та жанри. Вісник ЗХІ. Ужгород: Закарпат. акад. мистец., 2014. 134 с.

2. В'юник А.О. Українська графіка XI початку ХХ століття. К: Мистецтво, 1994. 328 с.

3. Даниленко В.Я. Дизайн України у світовому контексті художньо-проектної культури: Монографія. Харків: ХДАДМ; Колорит, 2005. 244 c.
4. Енциклопедія Українознавства. В 10 т. / гол. ред. В. Кубійович. Париж-Нью-Йорк. Львів: Молоде життя, 1954-1989. 2112 с.

5. Лебедев Любимов О.М. Психологія реклами. СПб: Питер, 2002. 108 с.

6. Мандель Б. Р. Психология рекламы: иллюстрированное учебное пособие для студентов высших учебных заведений. Москва Берлин: Директ-Медиа, 2019. С. 381.

7. Храмова-Баранова О. Традиції та сучасність в мистецтві плакату. М-во культ. України; Нац. акад. кер. кадрів культ. і мистец. К: НАКККіМ, 2019. 275 c.

\section{References}

1. Andrejkanich A.I. (2014). Definition of the concept of the poster, its types, and genres. Uzhgorod: Zakarpat. akad. mistec. [in Ukrainian].

2. V'yunik A.O. (1994). Ukrainian graphics of XI - beginning of XX century. Kyiv: Mistectvo [in Ukrainian].

3. Danilenko V.Ya. (2005). Design of Ukraine in the world context of art and design culture: Monograph. Kharkiv: HDADM; Kolorit [in Ukrainian].

4. Kubijovich V. (Eds.). (1954-1989). Encyclopedia Ukrayinoznavstva. Paris-New York. Lviv: Molode zhittya [in Ukrainian].

5. Lebedev Lyubimov O.M. (2002). Psychology of advertising. SPb: Piter [in Russia].

6. Mandel B. R. (2019). Advertising Psychology: An Illustrated Study Guide for Graduate Students. Moscow Berlin: Direkt-Media [in Russia].

7. Hramova-Baranova O. (2019). Traditions and modernity in poster art. Kyiv: NAKKKiM [in Ukrainian].

Стаття надійшла до редакиії 28.08.2020 Прийнято до друку 21.09.2020 